\title{
PEMBUATAN TUTORIAL CARA CEPAT MEMBACA DAN BERHITUNG PADA ANAK BERBASIS MULTIMEDIA MENGGUNAKAN MACROMEDIA FLASH 8
}

\author{
Ade Putra, Asnawati, Eko Suryana \\ Program Studi Sistem Informasi Fakultas Ilmu Komputer Universitas Dehasen Bengkulu \\ Jl. Meranti Raya No. 32 Kota Bengkulu 38228 Telp. (0736) 22027, 26957 Fax. (0736) 341139
}

\begin{abstract}
In the future today children today tend to be interested in playing the game from the study, because the development of the game world is now more rapidly and attractive compared to developments in the world of education, this is what makes children more interested in playing games than on learning. in addition, the old learning methods of reading and exercise, most of the children in modern times are now less interested and tend to be lazy to learn such a way. require a way for children to play and indirectly while learning. Computer-based teaching tool is expected to help overcome this problem. in addition, teaching tool like this can also ease the burden on teachers, so that the learning process can run well and the materials being taught can be understood by students. through learning how to use a computer, a lesson can be delivered in an interactive form and can illustrate a concept through animation, sound and attractive demonstration. this application allows students to learn without a time limit. The purpose of the research to make reading tutorial how to quickly and counting in child-based multimedia using macromedia flash 8.0. teaching tool that utilizes computers to deliver the materials to be taught so-called computer assisted instruction (cai). computer assisted instruction is a computerbased teaching aids with an interactive program. by using this device, the learning process becomes more active. this device can be used as a primary tool or a teaching tool. Based on the results of this study concluded that the tutorial how to quickly learn and numeracy can add to the spirit of learning students, this is because students are actively involved and participate in learning using this tutorial, so that learning becomes fun, the students begin to mention the numbers and letters with its own language, though still with the help of a teacher.
\end{abstract}

Key words : Tutorial, Multimedia, Macromedia Flash

\section{INTISARI}

Kebanyakan anak-anak zaman sekarang cenderung tertarik bermain game dari pada belajar, dikarenakan perkembangan dunia game sekarang lebih pesat dan menarik dibandingkan perkembangan di dunia pendidikan, hal inilah yang membuat anak-anak lebih tertarik bermain game dari pada belajar. selain itu, metode belajar yang lama yaitu membaca dan latihan, sebagian besar anak-anak di zaman modern sekarang kurang berminat dan cenderung malas dengan cara belajar seperti itu. karenanya dibutuhkan suatu cara agar anak bermain dan secara tidak langsung sambil belajar. Perangkat ajar berbasis komputer bisa membantu mengatasi permasalahan-permasalahan ini. di samping itu, perangkat ajar seperti ini juga dapat meringankan beban para pengajar, sehingga proses pembelajaran bisa berjalan dengan baik dan bahan-bahan yang diajarkan bisa dimengerti oleh siswa. melalui cara belajar dengan menggunakan komputer, pelajaran bisa disampaikan dalam bentuk interaktif dan bisa mengilustrasikan sebuah konsep melalui animasi, suara dan demonstrasi yang atraktif. aplikasi ini memperbolehkan siswa untuk belajar tanpa batas waktu. Adapun tujuan dari penelitian ini adalah untuk membuat tutorial cara cepat membaca dan menghitung pada anak berbasis multimedia menggunakan macromedia flash 8.0. Perangkat ajar yang memanfaatkan komputer untuk menyampaikan bahan-bahan yang akan diajarkan biasa disebut computer assisted instruction (cai). computer assited instruction adalah alat bantu pengajaran berbasiskan komputer dengan program yang interaktif. dengan menggunakan perangkat ini, proses belajar menjadi lebih aktif. perangkat ini dapat digunakan sebagai alat utama atau alat bantu pengajaran. Berdasarkan hasil penelitian dapat disimpukan bahwa tutorial cara cepat belajar dan berhitung ini dapat menambah semangat belajar siswa-siswi, hal ini dikarenakan siswa-siswi terlibat aktif dan ikut berpartisipasi dalam pembelajaran menggunakan tutorial ini, sehingga pembelajaran menjadi menyenangkan, siswa mulai mampu menyebutkan angka dan huruf dengan bahasanya sendiri meski masih dengan bantuan guru.

Kata Kunci : Tutorial, Multimedia, Macromedia Flash

\section{PENDAHULUAN}

Perangkat ajar berbasis komputer bisa membantu mengatasi permasalahan-permasalahan ini. Di samping itu, perangkat ajar seperti ini juga dapat meringankan beban para pengajar, sehingga proses pembelajaran bisa berjalan dengan baik dan bahanbahan yang diajarkan bisa dimengerti oleh siswa. Melalui cara belajar dengan menggunakan komputer, pelajaran bisa disampaikan dalam bentuk interaktif dan bisa mengilustrasikan sebuah konsep melalui animasi, suara dan demonstrasi yang atraktif. Aplikasi ini memperbolehkan siswa untuk belajar tanpa batas waktu.

Sistem pembelajaran dengan komputer akan dapat membantu memahami materi, karena dengan komputer memungkinkan untuk menghadirkan 
bentuk pembelajaran yang menarik. Dengan teknologi komputer dapat disajikan media pembelajaran secara tekstual, audio maupun visual.

Tujuan dari penelitian ini adalah untuk membuat Tutorial Cara Cepat Membaca dan Menghitung Pada Anak Berbasis Multimedia Menggunakan Macromedia Flash 8.0.

\section{KAJIAN PUSTAKA}

\section{A) Pengertian Perangkat Ajar}

Perangkat ajar merupakan perangkat lunak pengajaran dengan bantuan komputer, penyampaian materinya dirancang dalam bentuk multimedia agar lebih memudahkan siswa dalam memahami materi baik dalam bentuk aplikasi desktop maupun berbasis web. Suatu bentuk perangkat ajar dapat digunakan untuk mendukung pengajaran dan pelatihan, namun dalam penyampaiannya dibutuhkan pula seorang pendamping atau guru dalam mempelajari suatu materi agar siswa tidak salah menafsirkan suatu pelajaran. (Bahrami, $2000: 23$ )

Perangkat ajar yang memanfaatkan komputer untuk menyampaikan bahan-bahan yang akan diajarkan biasa disebut Computer Assisted Instruction (CAI). Computer Assited Instruction adalah alat bantu pengajaran berbasiskan komputer dengan program yang interaktif. Dengan menggunakan perangkat ini, proses belajar menjadi lebih aktif. Perangkat ini dapat digunakan sebagai alat utama atau alat bantu pengajaran. (Suparto, 2006 : 227)

Berdasarkan pengertian di atas, dapat disimpulkan bahwa perangkat ajar adalah suatu perangkat lunak yang dibuat dengan bantuan komputer dan berfungsi sebagai alat pembelajaran bagi yang membutuhkannya, sedangkan tujuan dari pembuatan perangkat ajar antara lain untuk meningkatkan semangat belajar siswa sehingga penyerapan materi semakin cepat dan siswa tidak merasa jenuh.

\section{B) Pengertian Membaca}

Membaca adalah suatu proses yang dilakukan serta dipergunakan oleh pembaca untuk memperoleh pesan yang hendak disampaikan oleh penulis melalui media kata-kata atau bahasa tulis. Suatu proses yang menuntut agar kelompok kata yang merupakan suatu kesatuan akan terlihat dalam pandangan sekilas, dan agar makna kata-kata secara individual akan dapat diketahui. Kalau hal ini tidak terpenuhi, maka pesan yang tersurat dan yang tersirat tidak akan tertangkap atau dipahami, dan proses membaca itu tidak terlaksana dengan baik (Sutisna, 2013).
Membaca dapat pula dianggap sebagai suatu proses untuk memahami yang tersirat dalam yang tersurat, yakni memahami makna yang terkandung di dalam kata-kata yang tertulis. Makna bacaan tidak terletak pada halaman tertulis tetapi berada pada pikiran pembaca. Demikianlah makna itu akan berubah, karena setiap pembaca memiliki pengalaman yang berbeda-beda yang dipergunakan sebagai alat untuk menginterpretasikan kata-kata tersebut.

Setiap guru bahasa haruslah menyadari serta memahami benar-benar bahwa membaca adalah suatu metode yang dapat dipergunakan untuk berkomunikasi dengan diri kita sendiri dan kadangkadang dengan orang lain yaitu mengomunikasikan makna yang terkandung atau tersirat pada lambanglambang tertulis.

\section{C) Pengertian Multimedia}

Multimedia adalah pemanfaatan komputer untuk membuat dan menggabungkan teks, grafik, audio, gambar bergerak (video dan animasi) dengan menggabungkan link dan tool yang memungkinkan pemakai melakukan navigasi, berinteraksi, berkreasi dan berkomunikasi. (Suyanto, $2003: 14$ )

Multimedia umumnya meliputi kombinasi dari tiga elemen sound (suara), image (gambar), dan text (naskah). Tapi untuk dikatakan sebuah multimedia, tidak selalu ketiga elemen tersebut ada, dalam produksi multimedia berbeda-beda dari aplikasi yang satu dengan aplikasi yang lain. Kombinasi dua atau tiga elemen-elemen ini dianggap multimedia, karena digunakan alat-alat (tools) dan ketrampilan (skills) yang sama.

Dengan media khusus, aneka media tersebut dapat diolah untuk menimbulkan efek unik seperti simulasi dan animasi yang biasanya dipakai untuk persentasi dan promosi.

Pentingnya multimedia karena salah satunya dipakai sebagai media untuk pengajaran. Di samping itu pada Abad 21 ini multimedia segera menjadi keterampilan dasar yang sama pentingnya dengan keterampilan membaca. Sesungguhnya multimedia mengubah hakikat membaca itu sendiri. Multimedia menjadikan kegiatan membaca itu dinamis dengan memberi dimensi baru pada kata-kata.

\section{D) Pengertian Animasi}

Animasi merupakan kumpulan gambar yang ditampilkan secara bergantian sehingga akan terlihat bergerak. Pergerakan dari animasi ini akan lebih mudah dicerna oleh pemakai dari gambar diam, memang lebih komunikatif dibandingkan animasi 
hal-hal tertentu. Sedangkan animasi dibuat khusus untuk mendukung konsep ilustrasi yang mengharuskan adegan gambar yang bergerak. (Riberu, $2001: 31$ )

Berikut ini beberapa animasi yang terdapat pada Macromedia Flash 8.0 :

1) Animasi Frame To Frame

Animasi ini berfungsi untuk membuat animasi pergerakan dengan menggunakan setiap frame yang ada.

2) Animasi Motion Tween

Animasi ini berfungsi untuk membuat animasi pergerakan melalui motion tween.

3) Animasi Motion Guide

Animasi ini digunakan untuk membuat animasi pergerakan objek mengikuti bentuk dari garis.

4) Animasi Masking

Animasi ini berfungsi untuk menampilkan objek yang semula disembunyikan, dengan bantuan dari objek lain.

5) Animasi Motion Shape

Animasi ini berguna untuk membuat animasi perubahan bentuk dari satu bentuk ke bentuk yang lain.

6) Animasi Motion Tween Rotate

Animasi ini digunakan untuk membuat animasi perputaran, baik berutar ditempat maupun berputar sambil berjalan.

\section{METODOLOGI PENELITIAN}

Metode penelitian yang digunakan dalam pembuatan perangkat ajar ini adalah metode pengembangan sistem, yang bertujuan untuk mengembangkan metode penggunaan perangkat pembelajaran dari cara manual dengan gambar serta alat peraga yang menggunakan media sistem Animasi dan Visualisasi. Dimana sistem yang dipakai pada saat ini tidak memaksimalkan hasil dalam belajar siswa dikarenakan masih secara konvensional, yaitu menggambar dipapan tulis dan menulis dipapan tulis.

Pengembangan sistem (systems development) dapat berarti menyusun suatu sistem yang baru untuk menggantikan sistem yang lama secara keseluruhan atau memperbaiki sistem yang telah ada, sehingga diharapkan proses pembelajaran dapat meningkatkan daya tarik dan motivasi siswa dalam belajar.

Software dan hardware yang digunakan dalam penelitian ini adalah:

a) Sistem Operasi Windows 7

b) Program Aplikasi Macromedia Flash 8.0 untuk pembuatan tutorial

c) Adobe Photoshop CS3 untuk pengaturan dan pengeditan gambar.
Adapun Hardware yang digunakan dalam penelitian ini adalah:
a) Processor Intel $\mathbb{R}$ Core ${ }^{\mathrm{TM}} 2$ Duo CPU E7500 @ $2.93 \mathrm{GHz} 2.94 \mathrm{GHz}$
b) Memory(RAM) 1,00 GB DDR3
c) LCD Monitor Dell
d) Speaker Simbada
e) Keyboard dan Mouse USB
f) Printer Canon Pixma iP2700

Sistem pembelajaran yang selama ini umum digunakan pada PAUD untuk memberikan pelajaran tentang cara cepat membaca dan berhitung, melalui konvensional yaitu dengan menulis dan menggambar di papan tulis, adapun cara pembelajaran secara faceto-face ternyata memiliki kelemahan. Salah satunya adalah tingkat penerimaan setiap siswa yang berbedabeda sehingga ada siswa yang mengerti, kurang mengerti dan bahkan tidak sama sekali. Berdasarkan analisa sistem lama yang masih terdapat kelemahan dan kekurangan, maka penulis ingin membantu dengan membuat tutorial cara cepat membaca dan menghitung pada anak berbasis multimedia menggunakan aplikasi Macromedia Flash.

Dalam perancangan sistem baru yaitu Pembuatan Tutorial cara cepat membaca dan menghitung pada anak berbasis multimedia ini, penulis akan merancang struktur menu yang terdiri dari, Menu Pembuka, Menu Utama, Menu Cara Cepat Membaca, Menu Cara Menghitung Angka, dan Menu Penutup.

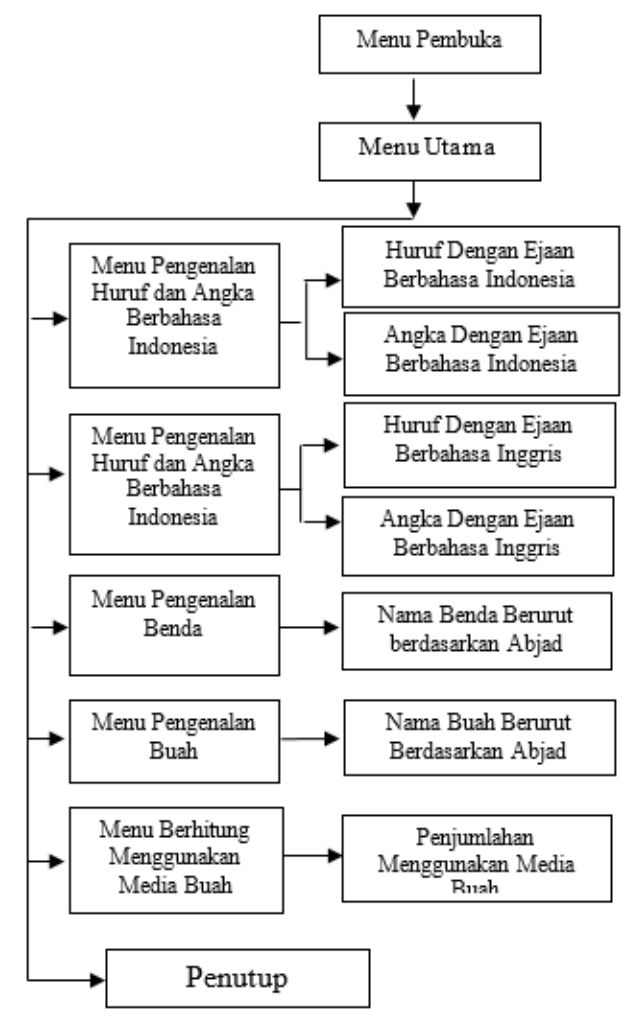

Gambar 1. Struktur Menu 
Setelah pembuatan program Pembuatan Tutorial Cara Cepat Membaca dan Menghitung selesai, tahap selanjutnya adalah pengujian program. Pengujian ini ada dua macam yaitu pengujian performance system dan pengujian dilingkungan user. Pengujian performance system adalah pengujian sejauh mana program tutorial cara cepat membaca dan menghitung ini dapat digunakan pada perangkat computer dengan jenis yang berbeda-beda. Sedangkkan pengujian dilingkungan user adalah menguji program apakah program bisa digunakan oleh tenaga pendidik sebagai perangkat pembelajaran yang berguna bagi siswa atau tidak.

\section{PEMBAHASAN}

Adapun hasil penelitian ini adalah terciptanya aplikasi Tutorial Cara Cepat Belajar dan Berhitung pada anak berbasis Multimedia yang didalamnya lebih banyak didominasi oleh animasi gambar, teks serta suara. Dengan adanya tutorial ini dapat membantu atau memberikan alternatif lain bagi guru dalam penyampaian materi cara cepat membaca dan berhitung pada anak. Diharapkan dari pembuatan perangkat ajar ini dapat meningkatkan semangat belajar siswa sehingga materi semakin cepat diserap dan siswa tidak merasa jenuh.

Pembuatan program Tutorial Cara Cepat Belajar dan Berhitung pada anak berbasis Multimedia ini mengunakan aplikasi Macromedia Flash 8 kemudian file disimpan dengan format yang berekstensi .exe, agar program mudah dijalankan di setiap komputer tanpa harus menginstall terlebih dahulu aplikasi Macromedia Flash 8. File dalam bentuk Exe yang dihasilkan berukuran 3.07 MB. File yang diberikan ke user tidak dapat diubah kembali.

\section{A) Menu Pembuka}

Pada Menu Pembuka berisi tulisan Tutorial Cara Cepat Membaca dan Berhitung dengan animasi teks, dilengkapi dengan instrument musik. Selain itu di Menu pembuka ini terdapat gambar animasi siswa pra sekolah.

Pada menu pembuka Gambar 2 terdapat tombol Mulai. Pengunjung tinggal memilih tombol Mulai yang terdapat di bagian bawah jika ingin ke menu Utama.

\section{B) Мепи Utama}

Menu Utama Gambar 3 berisi animasi tulisan Tutorial Cara Cepat Membaca dan Berhitung dengan animasi teks, diiringi instrument musik. Pada Menu Utama terdapat 6 (Enam) tombol pilihan untuk masuk ke menu selanjutnya. 3 tombol untuk masuk ke Menu
Profile, Menu Pendidikan, Menu Pendaftaran, dan 1 tombol untuk menuju ke Menu Penutup.

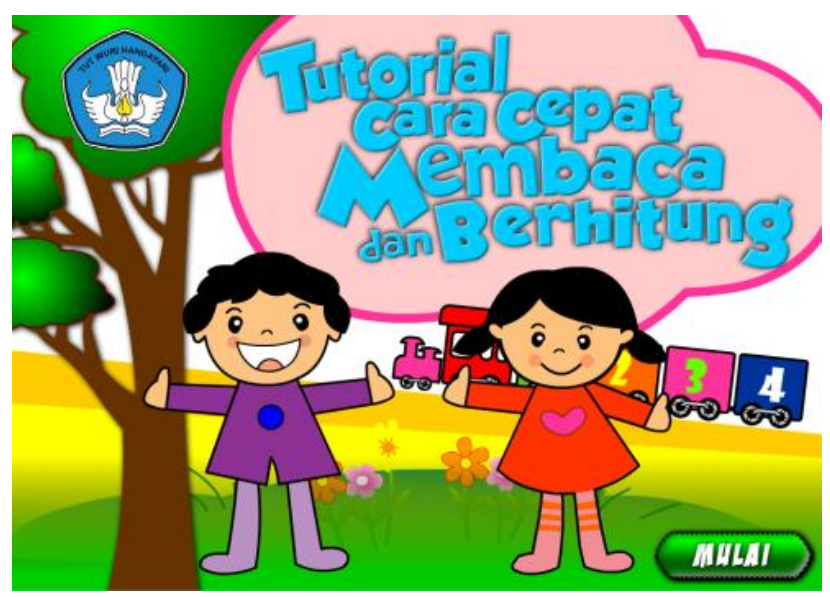

Gambar 2. Tampilan Menu Pembuka

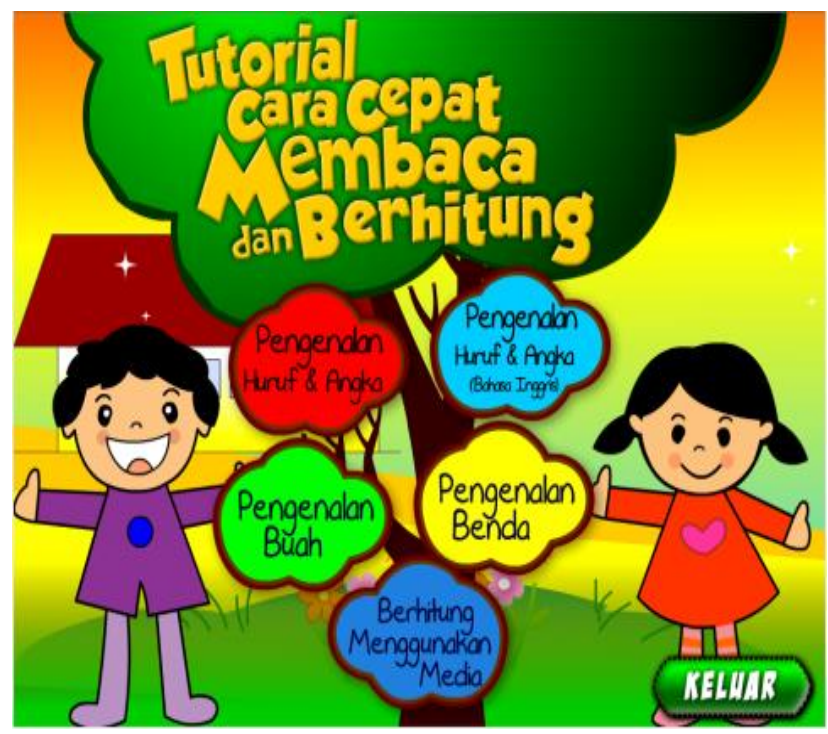

Gambar 3. Tampilan Menu Utama

\section{C) Menu Pengenalan Huruf dan Angka}

Menu Pengenalan Huruf dan Angka Gambar 4 berisi animasi tulisan Pengenalan Huruf dan Angka dengan animasi teks, diiringi instrument musik. Pada Menu Pengenalan Huruf dan Angka terdapat 4 (Empat) tombol pilihan untuk masuk ke menu selanjutnya. 2 tombol untuk masuk ke Menu Abjad dan Menu Angka, 2 tombol untuk menuju ke menu Menu Utama, dan ke Menu Penutup.

Selain itu, pada menu Pengenalan Huruf dan Angka terdapat animasi gambar kartun dan animasi tumbuhan. Menu Pengenalan Huruf dan Angka merupakan Menu untuk masuk ke Sub Menu Pengenalan Abjad dan Sub Menu pengenalan Angka.

\section{D) Sub Menu Pengenalan Abjad}

Sub Menu Pengenalan Abjad Gambar 5 berisi animasi tulisan Pengenalan Huruf Cara cepat mengenal abjad, diiringi instrument musik. Pada 
Menu ini terdapat 5 (Lima) tombol pilihan untuk ke menu selanjutnya. 2 tombol untuk ke huruf selanjutnya, 3 tombol selanjutnya untuk menuju ke Pengenalan Angka, menuju ke menu utama, kemudian untuk keluar aplikasi.

Pada sub menu ini terdapat animasi, tampilan Abjad mulai dari Huruf A sampai Z, yang akan tampil saat siswa menekan tombol panah yang terdapat disamping huruf. Panah menghadap ke kanan untuk huruf selanjutnya, sedangkan panah yang menghadap ke kiri menuju ke huruf sebelumnya.

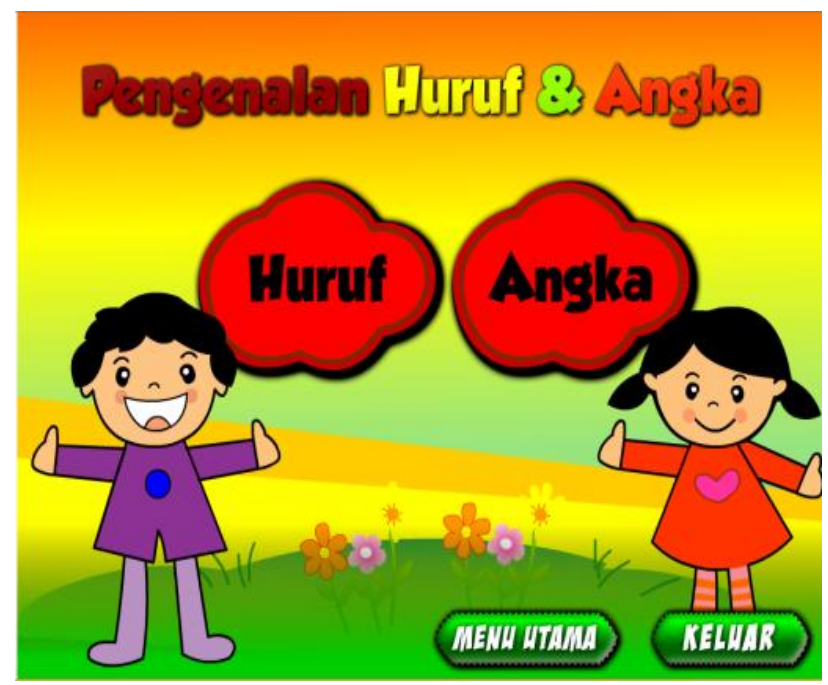

Gambar 4.Tampilan Menu Pengenalan Huruf dan Angka

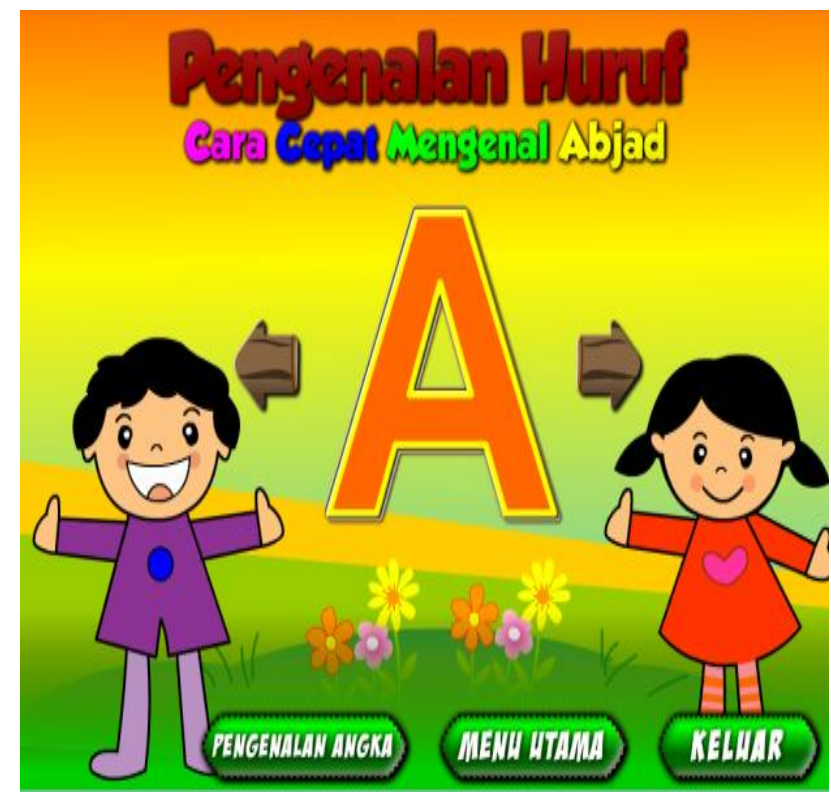

Gambar 5. Tampilan Sub Menu Pengenalan Huruf

\section{E) Sub Menu Pengenalan Angka}

Sub Menu Pengenalan Angka Gambar 6 berisi animasi tulisan Pengenalan Angka Cara cepat mengenal Angka, diiringi instrument musik. Pada Menu ini terdapat 5 (Lima) tombol pilihan untuk ke menu selanjutnya. 2 tombol untuk ke Angka selanjutnya, 3 tombol selanjutnya untuk menuju ke
Pengenalan Huruf, menuju ke menu utama, kemudian untuk keluar aplikasi.

Pada sub menu ini terdapat animasi, tampilan Angka yang terpisah, dimulai dari Angka 1 sampai 10, yang akan tampil saat siswa menekan tombol panah yang terdapat disamping angka. Panah menghadap ke kanan untuk angka selanjutnya, sedangkan panah yang menghadap ke kiri menuju ke angka sebelumnya.

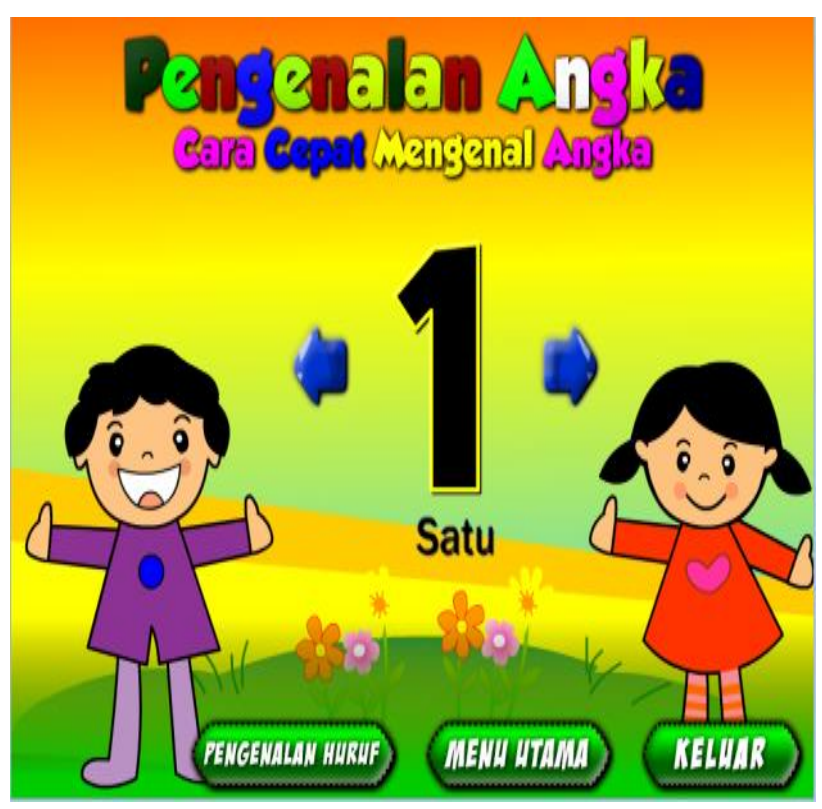

Gambar 6. Tampilan Sub Menu Pengenalan Angka

\section{F) Menu Pengenalan Huruf dan Angka Bahasa Inggris}

Menu Pengenalan Huruf dan Angka Bahasa Inggris Gambar 7 merupakan menu yang berisi pengenalan huruf dan angka dalam bahasa Inggris. Menu ini berisi animasi tulisan Pengenalan Hurup dan Angka Bahasa Indonesia dengan animasi teks, diiringi instrument musik. Pada Menu Pengenalan Huruf dan Angka Bahasa Inggris terdapat 4 (Empat) tombol pilihan untuk masuk ke menu selanjutnya. 2 tombol untuk masuk ke sub menu Abjad, dan sub menu angka. 2 (dua) tombol selanjutnya untuk menuju ke menu Utama, dan 1 tombol untuk keluar.

\section{G) Sub Menu Pengenalan Huruf Bahasa Inggris}

Sub Menu Pengenalan Abjad Gambar 8 berisi animasi tulisan Pengenalan Huruf Cara cepat mengenal abjad, diiringi instrument musik. Pada Menu ini terdapat 5 (Lima) tombol pilihan untuk ke menu selanjutnya. 2 tombol untuk ke huruf selanjutnya, 3 tombol selanjutnya untuk menuju ke Pengenalan Angka, menuju ke menu utama, kemudian untuk keluar aplikasi.

Pada sub menu ini terdapat animasi, tampilan Abjad mulai dari Huruf A sampai Z beserta ejaan 
dalam bahasa inggris, yang akan tampil saat siswa menekan tombol panah yang terdapat disamping huruf. Panah menghadap ke kanan untuk huruf selanjutnya, sedangkan panah yang menghadap ke kiri menuju ke huruf sebelumnya.

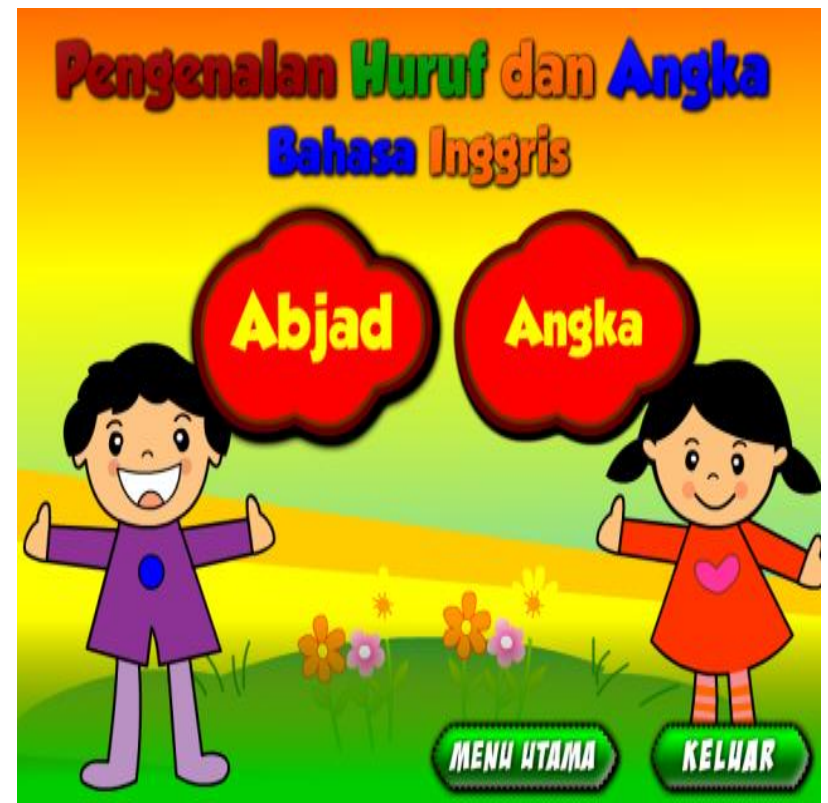

Gambar 7. Tampilan Menu Pengenalan Huruf dan Angka Bahasa Inggris

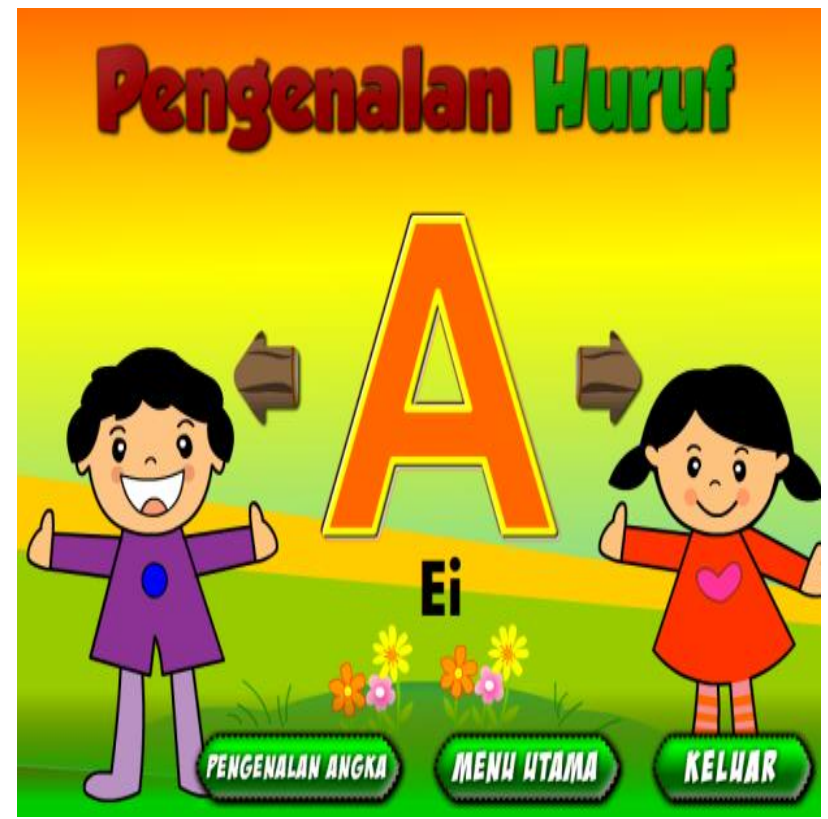

Gambar 8. Tampilan Sub Menu Pengenalan Huruf Bahasa Inggris

\section{H) Sub Menu Pengenalan Angka Bahasa Inggris}

Sub Menu Pengenalan Angka Gambar 9 berisi animasi tulisan Pengenalan Angka diiringi instrument musik. Pada Menu ini terdapat 5 (Lima) tombol pilihan untuk ke menu selanjutnya. 2 tombol untuk ke Angka selanjutnya, 3 tombol selanjutnya untuk menuju ke Pengenalan Huruf, menuju ke menu utama, kemudian untuk keluar aplikasi.
Pada sub menu ini terdapat animasi, tampilan Angka yang terpisah, dimulai dari Angka 1 sampai 10 beserta ejaan dalam bahasa Inggris, yang akan tampil saat siswa menekan tombol panah yang terdapat disamping angka. Panah menghadap ke kanan untuk angka selanjutnya, sedangkan panah yang menghadap ke kiri menuju ke angka sebelumnya.

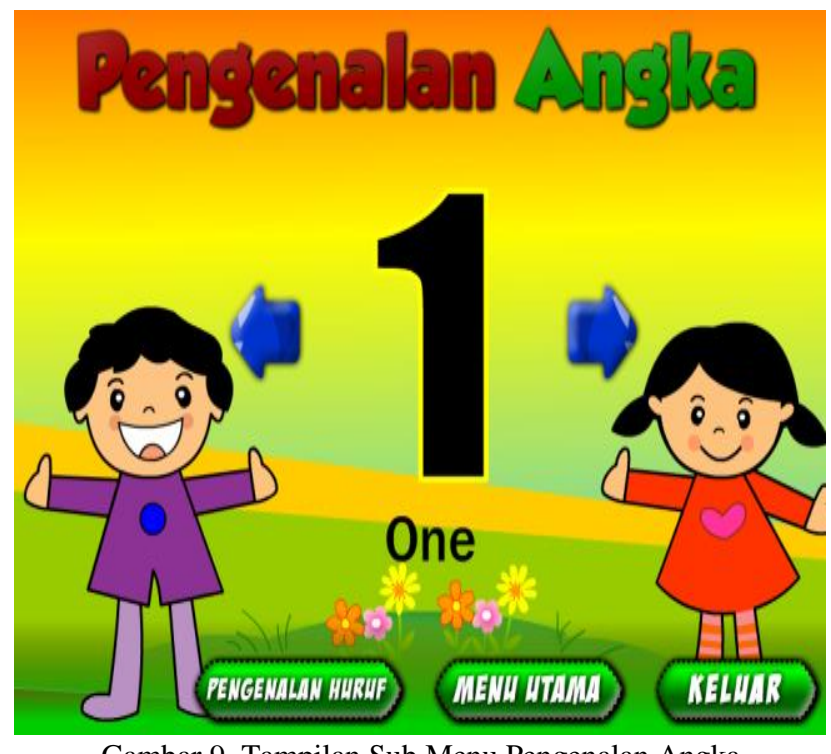

Gambar 9. Tampilan Sub Menu Pengenalan Angka Bahasa Inggris

\section{I) Menu Pengenalan Benda}

Menu Pengenalan Benda Gambar 9 merupakan menu untuk belajar mengenal benda-benda yang terdapat disekitar kita, yang sering dijumpai. Pada menu pengenalan benda ini terdapat tombol-tombol bergambar yang jika diklik akan menampilkan gambar benda yang dipilih. Terdapat 10 gambar yang ditampilkan. Pada menu pengenalan benda ini juga terdapat 2 tombol tambahan untuk kembali ke menu utama dan tombol keluar dari tutorial.

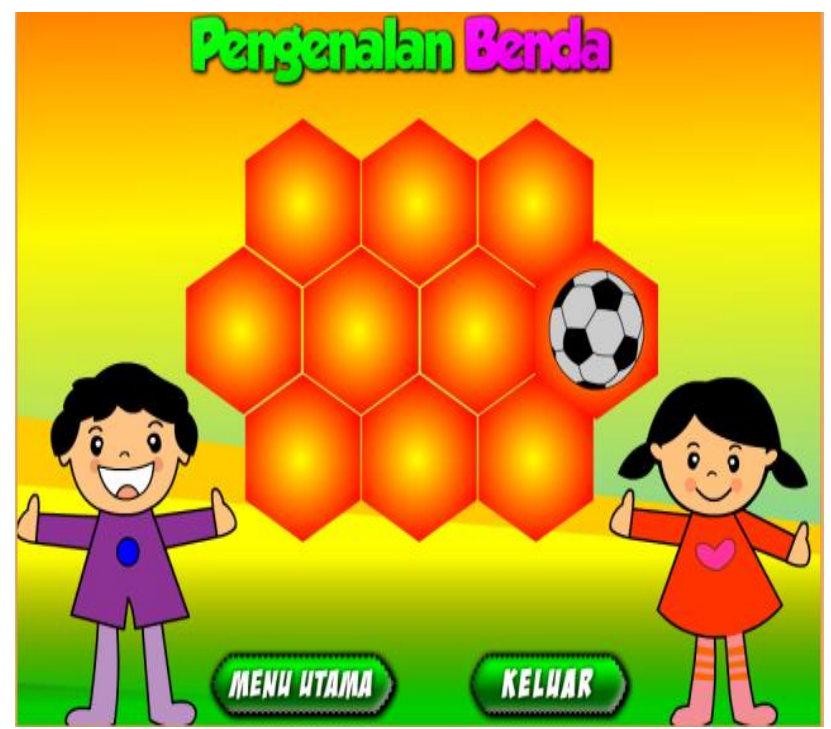

Gambar 10. Tampilan Menu Pengenalan Benda 


\section{J) Sub Menu Pengenalan Benda-Benda}

Sub Menu Pengenalan Benda-benda Gambar 11 merupakan menu tampilan benda secara keseluruhan setelah pengguna mengklik salah satu menu. Terdapat animasi tulisan Pengenalan Benda pada bagian atasnya. Pada menu pengenalan benda ini, disamping gambar benda terdapat 2 (dua) tombol, jika tombol yang menghadap sebelah kanan diklik akan menampilkan gambar selanjutnya, jika tombol menghadap ke kiri diklik maka akan menampilkan benda sebelumnya. Pada bagian bawah benda terdapat tulisan yang menjelaskan nama benda yang dimaksud. Pada menu pengenalan benda-benda ini juga terdapat 2 tombol tambahan untuk kembali ke menu utama dan tombol keluar dari tutorial.

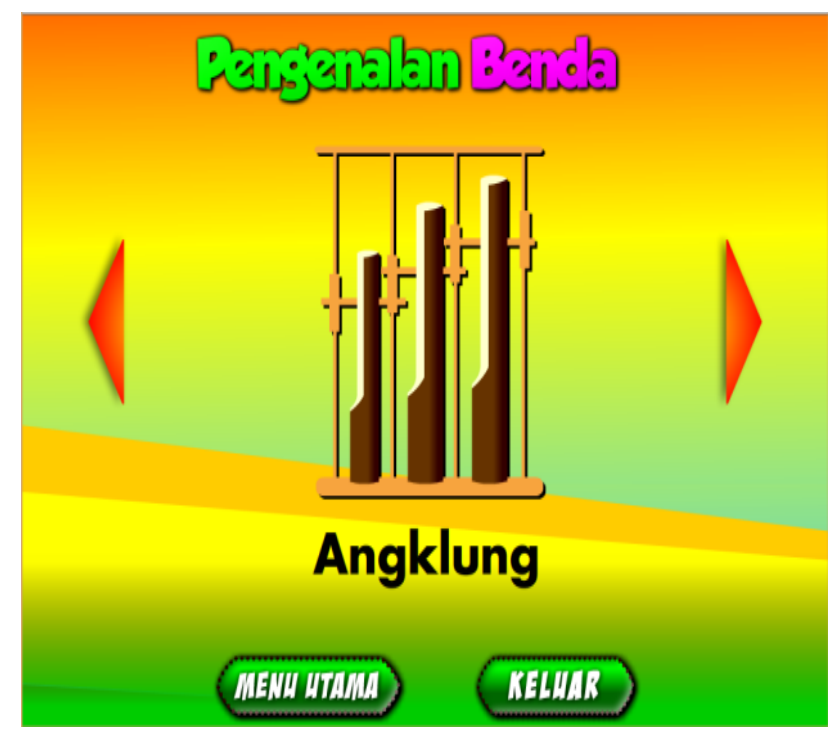

Gambar 11. Tampilan Sub Menu Pengenalan Benda

\section{K) Menu Pengenalan Buah}

Menu Pengenalan Buah Gambar 12 merupakan menu untuk belajar mengenal buah-buahan yang terdapat disekitar kita, yang sering dijumpai. Pada bagian atas Menu Pengenalan Buah terdapat animasi tulisan Pengenalan Buah. Pada menu pengenalan buah ini terdapat tombol-tombol bergambar yang jika diklik akan menampilkan gambar buah yang dipilih.

Di Menu Pengenalan Buah ini terdapat 10 gambar yang ditampilkan. Pada menu pengenalan buah ini juga terdapat 2 tombol tambahan untuk kembali ke menu utama dan tombol keluar dari tutorial.

\section{L) Sub Menu Pengenalan Buah}

Sub Menu Pengenalan Buah Gambar 13 merupakan menu tampilan buah secara keseluruhan setelah pengguna mengklik salah satu menu. Terdapat animasi tulisan Pengenalan Buah pada bagian atasnya. Pada menu pengenalan buah ini, disamping gambar buah terdapat 2 (dua) tombol, jika tombol yang menghadap sebelah kanan diklik akan menampilkan gambar selanjutnya, jika tombol menghadap ke kiri diklik maka akan menampilkan buah sebelumnya. Pada bagian bawah buah terdapat tulisan yang menjelaskan nama buah yang dimaksud. Pada menu pengenalan buah ini juga terdapat 2 tombol tambahan untuk kembali ke menu utama dan tombol keluar dari tutorial.

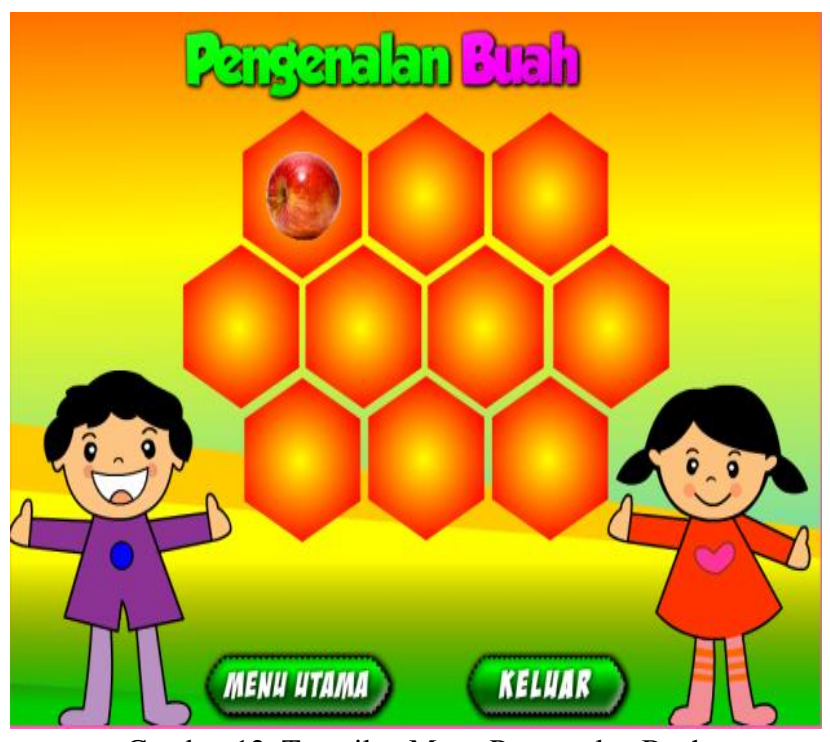

Gambar 12. Tampilan Menu Pengenalan Buah

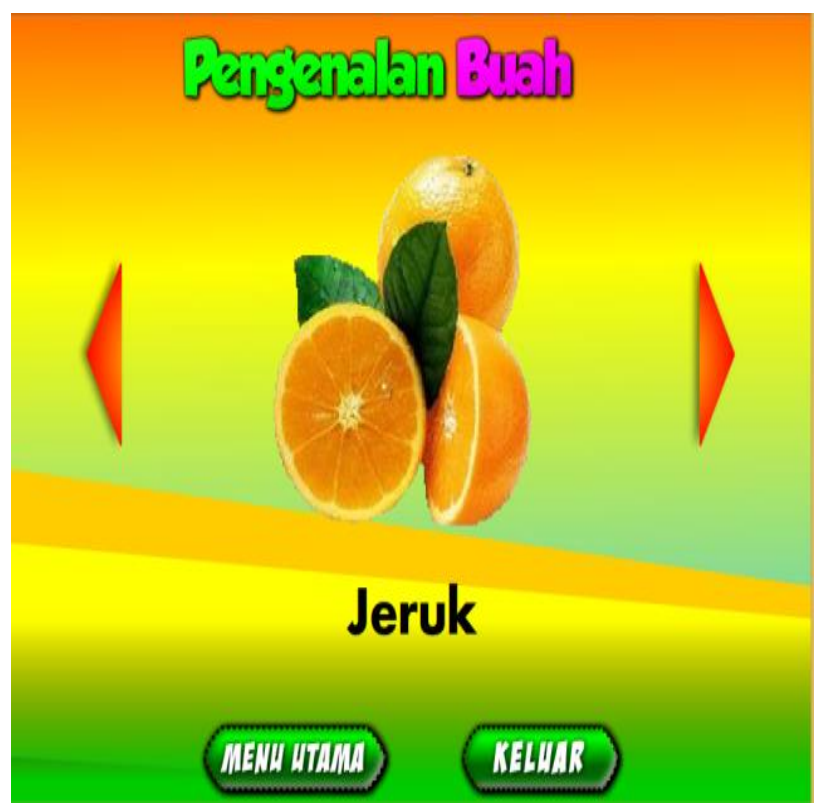

Gambar 13. Tampilan Sub Menu Pengenalan Buah

\section{M) Menu Berhitung Menggunakan Buah dan Benda}

Menu Berhitung Menggunakan Buah dan Benda Gambar 14 merupakan menu untuk belajar berhitung secara sederhana menggunakan buah dan benda yang terdapat disekitar kita, yang sering dijumpai. Pada bagian atas Berhitung Menggunakan Buah dan Benda terdapat animasi tulisan Berhitung Menggunakan Buah dan Benda. Pada menu berhitung menggunakan buah dan benda ini terdapat gambar buah atau benda 
yang dapat dihitung jumlahnya, kemudian terdapat tombol untuk menuju ke perhitungan selanjutnya.

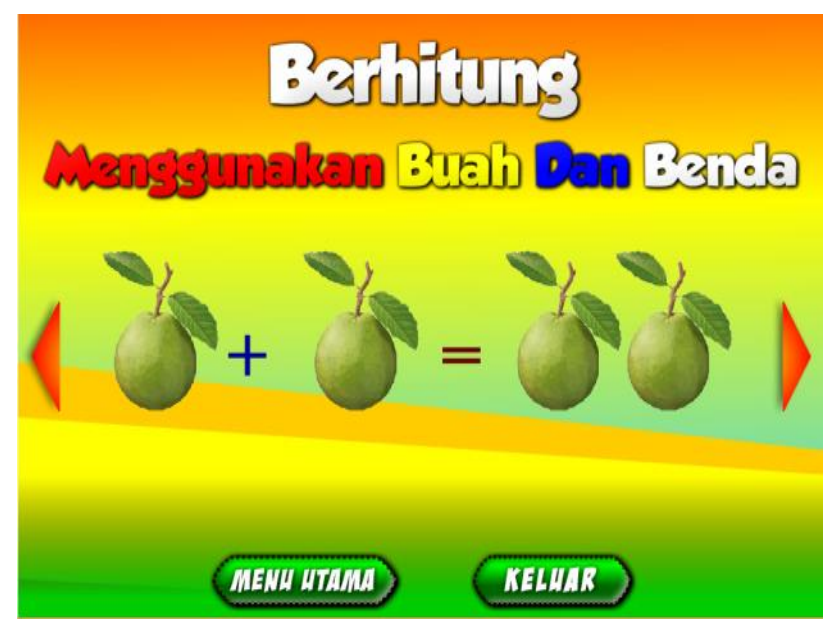

Gambar 14. Tampilan Menu Berhitung Menggunakan Buah dan Benda

\section{N) Мепи Penutup}

Menu Penutup Gambar 15 merupakan menu penutup dari program Tutorial cara Cepat Belajar Berhitung dan Membaca. Pada bagian atas terdapat tulisan Terima Kasih dan tulisan Sampai Jumpa. Pada menu penutup juga terdapat tombol keluar yang apabila tombol di klik maka aplikasi akan tertutup.

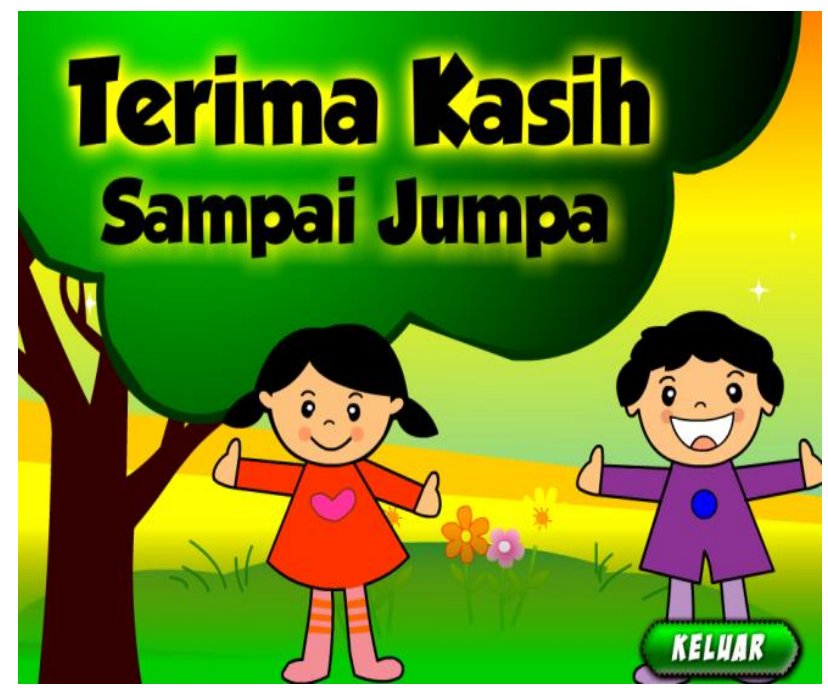

Gambar 15. Tampilan Menu Penutup

\section{O) Hasil Pengujian}

Setelah pembuatan program Pembuatan Tutorial Cara Cepat Membaca dan Menghitung selesai, tahap selanjutnya adalah pengujian program. Pengujian ini ada dua macam yaitu pengujian performance system dan pengujian dilingkungan user. Pengujian performance system adalah pengujian sejauh mana program tutorial cara cepat membaca dan menghitung ini dapat digunakan pada perangkat computer dengan jenis yang berbeda-beda. Setelah dilakukan pengujian Program Tutorial Cara Cepat Membaca dan
Menghitung pada 5 Unit Komputer berbeda jenis dan Spesifikasi program yang diujikan ini tidak mengalami sama sekali kendala. Sedangkan pengujian dilingkungan user adalah menguji program apakah program bisa digunakan oleh tenaga pendidik sebagai perangkat pembelajaran yang berguna bagi siswa atau tidak. Pada saat melakukan pengujian dilingkungan user, user kemudian diberikan kuesioner yang harus mereka jawab. Hasil pengujian ini disajikan pada Tabel 1, 2, dan 3.

Berdasarkan jawaban dari kuesioner ditentukan bahwa nilai jawaban a : 4, b:3, c :2, dan d : 1 dan didapati hasil jawaban responden :

Berdasarkan Tabel 3, maka diperolehlah jawaban Sangat Baik : 40,27\%, Baik : 58,33\%, Cukup Baik $: 1,40 \%$, dan Tidak Baik : 0\%. Hasil Rincian Dapat Dilihat Pada Gambar 16

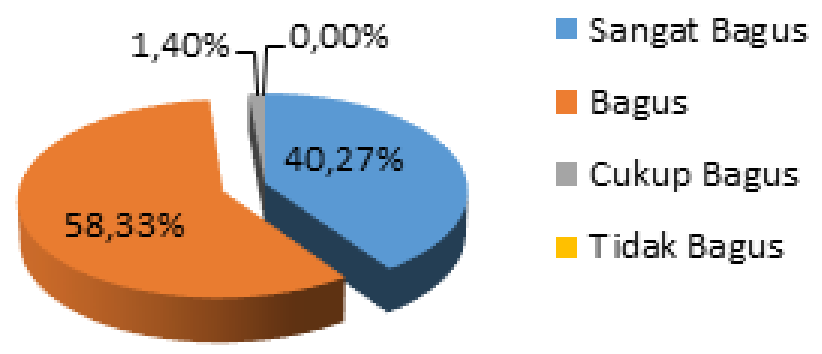

Gambar 16. Gambar Diagram Hasil Pengujian

Dari data yang telah diolah tersebut dapat disimpulkan bahwa Program Tutorial Cara Cepat Membaca dan Menghitung ini mudah dipahami dalam pennggunaannya serta tampilan yang disajikan terlihat baik dan menarik untuk di ajarkan kepada anak-anak, Setelah melakukan dua pengujian diatas maka dapat disimpulkan bahwa program ini berhasil.

\section{PENUTUP}

Tutorial Cara Cepat Belajar dan Berhitung ini dibuat dengan tampilan semenarik mungkin agar siswa-siswi tertarik untuk melihat dan belajar apa yang disampaikan oleh guru. Aplikasi ini dibuat dengan menggunakan Macromedia Flash 8.0. Selain dilengkapi dengan tulisan-tulisan penjelasan, pada tutorial ini terdapat juga animasi gambar, teks serta suara. File Utama Disimpan dengan ekstensi (.exe), dengan kapasitas file 8,45 Mega byte. Tutorial ini dapat dijalankan oleh pengguna di komputer ataupun laptop tanpa diharuskan menginstal software Macromedia Flash 8 dan file yang telah diberikan ke user tidak dapat diubah.

Berdasarkan hasil penelitian dan pembahasan pada Bab IV dapat disimpukan bahwa Tutorial Cara 
Tabel 1. Hasil Jawaban Responden

\begin{tabular}{|l|c|c|c|c|c|c|c|c|c|}
\hline \multicolumn{1}{|c|}{ NAMA } & P1 & P2 & P3 & P4 & P5 & P6 & P7 & P8 & P9 \\
\hline Devi Suryani, S. Pd. I & 4.00 & 3.00 & 3.00 & 4.00 & 4.00 & 4.00 & 4.00 & 4.00 & 3.00 \\
\hline Yani Raika, S. Kom & 2.00 & 3.00 & 3.00 & 3.00 & 3.00 & 3.00 & 3.00 & 3.00 & 4.00 \\
\hline Juwita & 3.00 & 3.00 & 3.00 & 4.00 & 4.00 & 3.00 & 4.00 & 3.00 & 4.00 \\
\hline Desi Lestari & 3.00 & 3.00 & 3.00 & 3.00 & 3.00 & 3.00 & 3.00 & 3.00 & 3.00 \\
\hline Jumi Hariarti & 4.00 & 3.00 & 4.00 & 4.00 & 3.00 & 4.00 & 4.00 & 4.00 & 4.00 \\
\hline Nanang Edi Harianto, S. Pd & 3.00 & 3.00 & 3.00 & 4.00 & 3.00 & 3.00 & 4.00 & 3.00 & 4.00 \\
\hline Suci Zumaini & 4.00 & 3.00 & 3.00 & 4.00 & 4.00 & 3.00 & 3.00 & 4.00 & 4.00 \\
\hline Darius Winarto, Sh & 3.00 & 4.00 & 3.00 & 4.00 & 3.00 & 3.00 & 4.00 & 3.00 & 3.00 \\
\hline
\end{tabular}

Tabel 2. Statistik

\begin{tabular}{|l|l|l|l|l|l|l|l|l|l|}
\hline & P1 & P2 & P3 & P4 & P5 & P6 & P7 & P8 & P9 \\
\hline VALID & 10 & 10 & 10 & 10 & 10 & 10 & 10 & 10 & 10 \\
\hline MISSING & 0 & 0 & 0 & 0 & 0 & 0 & 0 & 0 & 0 \\
\hline MEAN & 3.2500 & 3.1250 & 3.1250 & 3.7500 & 3.3750 & 3.2500 & 3.6250 & 3.3750 & 3.6250 \\
\hline MEDIAN & 3.00 & 3.00 & 3.00 & 4.00 & 3.00 & 3.00 & 4.00 & 3.00 & 4.00 \\
\hline MODUS & 3.00 & 3.00 & 3.00 & 4.00 & 3.00 & 3.00 & 4.00 & 3.00 & 4.00 \\
\hline STD. DEV & 0.70711 & 0.35355 & 0.35355 & 0.46291 & 0.51755 & 0.46291 & 0.51755 & 0.51755 & 0.51755 \\
\hline MIN & 2.00 & 3.00 & 3.00 & 3.00 & 3.00 & 3.00 & 3.00 & 3.00 & 3.00 \\
\hline MAX & 4.00 & 4.00 & 4.00 & 4.00 & 4.00 & 4.00 & 4.00 & 4.00 & 4.00 \\
\hline SUM & 26.00 & 25.00 & 25.00 & 30.00 & 27.00 & 26.00 & 29.00 & 27.00 & 29.00 \\
\hline
\end{tabular}

Tabel 3. Hasil Pengujian

\begin{tabular}{|c|c|c|c|c|c|}
\hline \multirow{2}{*}{ No. } & \multirow{2}{*}{ Kriteria } & \multicolumn{4}{|c|}{ Hasil Jawaban Responden } \\
\cline { 3 - 6 } & Pertanyaan 1 & A/SB & B/B & C/CB & D/TB \\
\hline 1 & Pertanyaan 2 & 1 & 4 & 1 & 0 \\
\hline 2 & Pertanyaan 3 & 1 & 7 & 0 & 0 \\
\hline 3 & Pertanyaan 4 & 6 & 2 & 0 & 0 \\
\hline 4 & Pertanyaan 5 & 3 & 5 & 0 & 0 \\
\hline 5 & Pertanyaan 6 & 2 & 6 & 0 & 0 \\
\hline 6 & Pertanyaan 7 & 5 & 3 & 0 & 0 \\
\hline 7 & Pertanyaan 8 & 3 & 5 & 0 & 0 \\
\hline 8 & Pertanyaan 9 & 5 & 3 & 0 & 0 \\
\hline 9 & Jumlah & 29 & 42 & 1 & 0 \\
\hline & Responden & \multicolumn{5}{c}{8} \\
\hline
\end{tabular}

Cepat Belajar dan Berhitung ini dapat menambah semangat belajar siswa-siswi, hal ini dikarenakan siswa-siswi terlibat aktif dan ikut berpartisipasi dalam pembelajaran menggunakan Tutorial ini, sehingga pembelajaran menjadi menyenangkan, siswa mulai mampu menyebutkan angka dan huruf dengan bahasanya sendiri meski masih dengan bantuan guru.

Penggunaan multimedia interaktif dengan kegiatan praktek menggunakan media berbasis komputer dapat dijadikan sebagai salah satu referensi untuk menciptakan pembelajaran yang aktif dan kondusif serta menyenangkan khususnya dalam pembelajaran mengenal huruf dan angka. Guru sebaiknya lebih kreatif dan selalu memberikan dorongan berupa pujian agar siswa lebih percaya diri dan termotivasi untuk melakukan hal yang lebih baik.

Siswa sebaiknya selalu aktif berpartisipasi dalam setiap kegiatan pembelajaran dengan cara memperhatikan penjelasan materi yang disampaikan guru dan aktif mengajukan pertanyaan apabila ada hal yang tidak dimengerti.

Sekolah sebaiknya memberikan kesempatan kepada siswa dan guru untuk lebih kreatif dalam menyampaikan materi pembelajaran dengan memanfaatkan berbagai media pembelajaran, terutama media yang terdapat di sekolah agar pembelajaran lebih bermakna dan sebagai upaya meningkatkan prestasi belajar siswa.

\section{DAFTAR PUSTAKA}

Agung, Gregorius. 2006. 6 Aplikasi Ampuh Flash 8. PT. Elex Media Komputindo, Jakarta

Bahrami, Ali. 1999, Object Oriented Systems Development, Irwin McGraw-Hill, New York

Binanto, Iwan. 2010, Multimedia Digital Dasar Teori Dan Pengembangannya, Penerbit Andi Yogyakarta 
Chandra, 2006. ActionScript Flash MX 2004. Penerbit Maxikom, Palembang

Darudiato, Suparto, Dkk. 2006, Analisis Dan Perancangan Aplikasi Perangkat Ajar Berbasis Multimedia Dengan Studi Kasus: Mata kuliah Analisa \& Perancangan Sistem Informasi. Jurusan Sistem Informasi, Fakultas Komputer, Universitas Bina Nusantara, Jakarta

Hartono, Jogiyanto, 2004, Pengenalan Komputer. Andi Offset, Yogyakarta

Hidayatullah, Priyanto, Dkk. 2008. Making Educational Animation Using Flash. Informatika, Bandung

Suyanto, Muhammad. 2005, MULTIMEDIA: Alat untuk Meningkatkan keunggulan bersaing. CV. ANDI OFFSET, Yogyakarta

Wijaya, Didik dan Hutasoit, Ahmad Parulian, 2003, Tip dan Trik Macromedia Flash MX dengan ActionScript, PT. Elex Media Komputindo, Jakarta 